\title{
Perspectives on Pinter Abroad
}

Harold Pinter (1930-2008) is inarguably one of the most influential modern British dramatists. The horizon of his literary, cultural and political project stretches far beyond the borders of his homeland, as well as beyond the theatrical and literary world. Thus, it can legitimately be claimed that Pinter belongs among the most prominent intellectuals of the $20^{\text {th }}$ century who left an important mark on the current international literary and political scene. Pinter started his artistic career with poetry writing in the early 1950s, and continued as a playwright, screenwriter, director, actor and political activist. In his career, he was awarded many literary and non-literary prizes for his literary achievements. Among the prominent ones are the Order of the British Empire, CBE (1966); the European Prize for Literature, Vienna (1973); The David Cohen British Literature Prize (1995); the Companion of Honour for services to Literature (2002); the Wilfred Owen Poetry Prize (2005); the Nobel Prize for Literature (2005); the European Theatre Prize (2006); and the Légion d'Honneur (2007). He has also been awarded honorary degrees from several British as well as foreign universities. His plays have been and are still being translated into numerous world languages in order to be published or performed in professional and amateur theatres. Similarly, his texts are studied by scholars in literature departments at universities around the world, among which the University of Maribor is no exception.

In 2012, the city of Maribor, Slovenia, is the proud holder of the prestigious European Capital of Culture title. Among a broad variety of projects, many of which began in 2011 and will continue in the years ahead, there has been plenty of opportunity for attending literary and other cultural events. Since the University of Maribor is an active partner in the Cultural Capital celebration, the Department of English and American Studies at the Faculty of Arts proposed a project dedicated to Pinter and his literary heritage.

The original intention was to focus on Pinter within the Slovene cultural borders; however, the decision was made to use the possibilities offered by the Cultural Capital support to expand the project beyond regional limits and invite to Maribor Pinter scholars and enthusiasts from various countries. In order to attract the general public as well as students and scholars of the humanities, the project was designed to feature cultural, didactic and scholarly events. Most events within the project entitled Pinter Abroad: Other Stages, Other Rooms were scheduled in late September of 2011; some started earlier and some are scheduled for the second half of 2012. These include a range of theatre performances: Pinter: In Other Rooms performed by a group of actors from the Pinter Centre for Research in Performance and Creative Writing from the University of London; a shadow theatre performance, Paper Pinter, carried out by the alternative theatre group Scena CARINA from Belgrade, Serbia; Old Times staged by the non-professional Maribor theatre group Studio gledališče; and The Dumb Waiter, which was staged in March 2011 in Ptuj. Apart from dramatic performances, the project also featured a symposium on various aspects of Harold Pinter's heritage, as well as three workshops, an acting one and two translation ones, intended for students interested in contemporary drama and literary translation. One of the latter two is scheduled for the second half of 2012. 
Pinter: In Other Rooms consisted of eight seldom-performed short plays by Harold Pinter. It was performed as an integrated evening rather than as a revue of plays; the performance located audiences in the world of the plays, transforming party venues into secret places of interrogation and torture or intimate spaces that reveal conversations that are by turns funny, sinister, absurd, and shocking. The plays included were Party Time, The Examination, Press Conference, Mountain Language, Night, Victoria Station and A New World Order. The performance was staged by the Pinter Centre for Research in Performance and Creative Writing from the University of London, produced by Neil Franklin, and directed by Robert Gordon and David Peimer ${ }^{1}$. With the Maribor performance, the group started a tour of eight European cities. Among other venues, they played in Prague (cf. Noble 2011; Prague Post 2011) and Thessaloniki (British Council 2011). In a change of pace, Paper Pinter was a shadow theatre performance, consisting of four short plays by Harold Pinter: Victoria Station, Family Voices, One for the Road and Mountain Language. The show's format of shadow theatre is reminiscent of the Turkish Karagoz theatre. Two actors operate paper puppets behind a canvas, using flash lights to project shadows onto the screen. The performance was produced by Nataša Milović and directed by Marko Kostić (Paper Pinter 2011). The language of the performance was Serbian, with subtitles projected onto the black wall behind the scene. For a more conventional theatre experience, Pinter's masterpiece Old Times, dealing with interpersonal relations and probing the unreliability of human memory, was staged by the amateur theatre group Studio gledališče (= Studio Theatre) from Maribor (Boštjančič 2011; for the theatre programme of the performance, see Stari časi 2011). The group was established over ten years ago under the artistic guidance of the professional Slovene theatre actor and director, Peter Boštjančič. In a different venue, The Dumb Waiter in new translation (cf. Pinter 2011), directed by Jernej Kobal, was staged at the Ptuj Town Theatre in Ptuj (Onič 2011), one of the oldest Slovene towns, which is one of Maribor's partners in the Cultural Capital Year project.

The two already implemented workshops within the project also dealt with Pinter's works. Landscape and Silence: Acting Pinter (September 2011) was led by Michael Devine from Acadia University in Nova Scotia, Canada. This workshop offered its participants an insight into the theatrical characteristics of Pinter's texts and a practical approach to staging them. The participants worked with Betrayal and The Caretaker and were familiarised with a variety of lively approaches and exercises to achieve the workshop's aims. Moving from performance to text, Pinter in Slovene was carried out within the Literary Translation Seminar in the Translation Studies program. The Translating Pinter workshop is scheduled for November 2012 and will also take place at the Faculty of Arts, University of Maribor. It will involve literary theoreticians, Pinter scholars and translators who have experience with translating Pinter into Slovene. Although primarily intended for students of translation, the workshop will also be open to the general public.

A major scholarly event within the project was the international conference on Harold Pinter's literary heritage in non-British contexts; this took place between 22 and 24 September 2011 in Maribor. The conference addressed a broad range of perspectives from several areas, such as reception and reviews of Pinter abroad, Pinter on international stages, (inter)cultural studies of

For a transcript of an interview with David Peimer, see Velinger 2011. 
Pinter, Pinter in translation (linguistic, stylistic and other aspects), teaching Pinter abroad, and Pinter and international politics. It involved over thirty participants from 12 countries, with eminent scholars such as Susan Hollis Merritt, Elizabeth Sakellaridou, and Mark Taylor Batty as keynote speakers.

In view of events organized within the Pinter Abroad project, its coordinators were addressed by the editors of ELOPE with an invitation to prepare a thematic issue of the journal featuring the project's main theme. After a call for papers was issued to all Pinter scholars who had been in contact with the project's organizers during these events, a selection of original scholarly articles was made on the basis of a blind peer review system, honouring the standards adopted by ELOPE. In this volume, the journal, which is usually subdivided into sections according to subject area, retains only the literature section, since the selected papers pertain to the common area of Pinter Studies, even though they vary in terms of the topics examined. These range widely in subject matter, from translation issues, theatrical practice and interpretation of Pinter's texts, to his political activism as reflected in his literary as well as non-literary undertakings.

To start, Łukasz Borowiec deals with specific literary translation issues, while opening general questions concerning the translatability of certain of Pinter's linguistic and stylistic features. He analyses typical elements of the playwright's language on the basis of his The Dwarfs: A Novel and its Polish translation. The contrastive analysis, which proves a useful method for this kind of research, is conducted through a study of three translation codes: lexical-semantic, cultural and aesthetic. The author is aware of the possible overlap of the three categories, a fact that he uses to show the complexity of Pinter's artistic vision in one of his earliest works.

Also focused on language, but from a more polemical perspective is Lilijana Burcar's study, which discusses Pinter's manipulative use of language; the listener is usually a victim of the speaker's psychological and physical abuse. The ultimate precision with which Pinter shapes his characters' utterances allows for intentional ambiguities and multi-layered meanings, which become a tool or even a torture weapon in the hands of the speaker. Burcar shows that (particularly for an unsuspicious audience) Pinter's discourse seems ordinary and neutral in using the Western rhetoric of humanitarian militarism; however, in context it leads the audience to hear the undertones that reveal another, usually unpleasant meaning. Burcar builds her argument on the example of Pinter's sketch The New World Order and other texts.

Being a theatre practitioner as well as a theatre scholar, Michael Devine addresses an aspect of Pinter's texts that dwells in both realms. He focuses on the theatrical elements of Pinter's plays that are by their nature closer to alternative than to conventional theatre. Making reference to two well-known plays, The Caretaker and Betrayal, he shows that the elements mainly responsible for Pinter's early plays being associated with the alternative British theatre movement in the late 1950 s are still present in the playwright's later works. These are, however, usually considered more theatrically conventional and, therefore, also approached with more classical analytical techniques. Devine suggests that the reason for the current misclassification in this respect is most likely Pinter's increased popularity and the commercial success of his plays. 
Moving from the stage to the podium, Andrew Goodspeed examines Harold Pinter's Nobel Prize lecture 'Art, Truth \& Politics' from a political perspective; however, he simultaneously makes a strong claim that the value of the Nobel address also lies in its potential for interpreting Pinter's art and aesthetic thought. The author is also critical of the reviews that appeared in the media after the awards ceremony; he argues that Pinter's speech was widely misreported as being most significant for its political attacks on the American President and the British Prime Minister. The paper successfully argues that the political tone of Pinter's Nobel Prize speech is congruent with his long-standing political statements and relatable to the dramatic work by which he is distinguished. A comparison is drawn to the Nobel Prize speeches of other distinguished recipients of this high award.

A similar attempt to place one work in the context of the oeuvre is the essay by Dilek Inan, who evaluates Pinter's Moonlight through the lens of his earlier plays, while defending the position that in this text, the playwright makes no substantial move away from salient features of his earlier works. She argues that, although Moonlight, his first full length play since Betrayal, appears to leave an impression different from the playwright's political plays, the similarity to these is considerable. According to Inan, Pinter in Moonlight reworks his own roots thematically, stylistically and spatially.

In an adventurous account, Andrea Peghinelli documents his encounter and cooperation with the Belarus Free Theatre, a dissident theatrical group that is critical of the totalitarian regime of the Belarusian President Aleksandr Lukashenko and must therefore operate in hiding. Furthermore, the article records how through Tom Stoppard, who visited Belarus Free Theatre in Minsk, the founders of the group, playwright and journalist Nikolai Khalezin and theatre producer Natalia Koliada, learned about Pinter's texts and started studying them. They eventually produced an original compilation of several Pinter texts and entitled it Being Harold Pinter. In the second part of his paper, Peghinelli analyses and evaluates the performance, with which Belarus Free Theatre has toured the world.

Renée von Paschen starts with an analysis of several of Pinter's stylistic features that can be found in The Dumb Waiter, lingering particularly on wit, black humour, sarcasm and irony, which are necessary components of this dark comedy, well fitted to the subgenre category of comedy of menace. The paper later examines the possibility of their translation into German and points to several translation problems. Additionally, von Paschen reports on the reception of this play in German cultural space. Moreover, with the use of contrastive methods, she analyses several different versions of The Dumb Waiter in German and English: the original Pinter text and its German translation, as well as Robert Altman's film adaptation and its dubbed German version. The analysis identifies several translation shifts, which are then presented in the final part of the paper.

In the concluding article, Elizabeth Sakellaridou, one of the keynote speakers from the scholarly conference in September 2011, views Pinter's respect for the individual and for humanity as a reflection of his cosmopolitanism, or visceral cosmopolitanism, as she chooses to name it. The dual approach she employs in her exploration of this issue forms a distinction as well as a bridge 
between Pinter's political actions in view of contemporary cosmopolitan discourse, and Immanuel Kant's more ethical understanding of cosmopolitanism. The author shows how Pinter's literary and non-literary oeuvre both reflect his consistently cosmopolitan stand.

In closing this overview and prologue, I would like to acknowledge the contribution of several institutions that helped and promoted the Pinter Abroad project - and, certainly, the individuals associated with them. The organizers wish to thank MARIBOR 2012 - European Capital of Culture, the University of Maribor, the British Council Slovenia, Narodni dom Maribor, Prva gimnazija Maribor, the Faculty of Arts at the University of Maribor, the Slovene Association for the Study of English, and the Faculty of Arts at the University of Ljubljana for their valuable cooperation and support, which directly or indirectly led to the idea and implementation of the current thematic issue of ELOPE.

\section{Tomaž Onič}

Editor of Volume IX - Spring

\section{Bibliography}

Boštjančič, P. 2011. Stari časi. Studio gledališče official web site. http://www.studio-gledalisce.si/stari-casi-2011 (accessed on 12 April 2012).

British Council, The. 2011. Pinter: In Other Rooms: a Performance by Goldsmiths' College Pinter Centre. http://www. britishcouncil.org/greece-arts-and-culture-pinter-in-other-rooms.htm (accessed on 12 April 2012).

Noble, W. 2011. The lesser known Pinter. The Prague Post. 14 October 2011. http://www.praquepost.com/blogs/ film/2011/10/14/the-lesser-known-pinter/.

Onič, T. 2011. Prevajanje Mutastega natakarja na povabilo Mestnega gledališča Ptuj. In ed. A. Strelec Bombek, Mutasti natakar (Strežni jašek), theatre programme: 14-5.

Paper Pinter. 2011. Scena Carina official web site. http://scenacarina.wordpress.com/2011/11/01/paper-pinter/ (accessed on 12 April 2012).

Pinter, H. 2011. Mutasti natakar (Strežni jašek), full text of the play translated by T. Onič. In ed. A. Strelec Bombek, Mutasti natakar (Strežni jašek), theatre programme: 19-36.

Pinter: In Other Rooms. 2011. Official statement for the press. http://events.ff.uni-mb.si/pinterabroad/documents/Pinter Centre Press\%20Pack.pdf (accessed on 29 September 2011).

Prague Post, The. 2011. Pinter: In Other Rooms comes to Divadlo Na zábradlí. 12 0ctober. http://www.praguepost.com/nightand-day/picks/10507-pinter-in-other-rooms-comes-to-divadlo-na-zabradli.html.

Stari časi. 2011. Gledališki list. Theatre programme. http://www.studio-gledalisce.si/wp-content/uploads/StariCasi.pdf (accessed on 12 April 2012).

Strelec Bombek, A., ed. 2011. Mutasti natakar (Strežni jašek). Theatre programme. Ptuj: MGL. http://www.mgp.si/si/images/ stories/Muhasti natakar Streni jaek Gledaliki list.pdf.

Velinger, J. 2011. Pinter's "In Other Rooms" at Divadlo Na Zábradlí. A transcript of an interview held at Radio Prague on 14 October 2011. http://www.radio.cz/en/section/arts/pinters-in-other-rooms-at-na-zabradli-theatre (accessed on 12 April 2012). 